\title{
The Latest Reports in Managing Acidic Sludge of Used Motor Oil Reprocessing Industries
}

\author{
Malek Hassanpour ${ }^{*}$
}

\author{
Department of Environmental science, UCS, Osmania University, Telangana State, India
}

\begin{abstract}
Used Motor Oils Recycling (UMOR) can be fulfilled in different ways depending on the quality and quantity of the fresh oil and the quality of the collected UMO. The Acidic Sludge (AS) is a byproduct of UMOR with hazardous effects and impacts on the environment. It yields 0.15 of each barrel (220 liters) of UMOR operation. The valid and relevant databases were used to discover the latest reports in managing the AS of UMOR operation. The findings of the current review were oriented towards the physical-chemical backbone of AS and its industrial exploitation. The chemical structure of AS was highlighted by a glance view in the recent reports. To sum up, it was recommended to utilize this valuable byproduct in many industrial applications as an additive.
\end{abstract}

Keyword: Used motor oil, Acidic sludge, Recycling, Screening, Projects.

\section{INTRODUCTION}

Lubricants used in today's industrial world can be categorized into four classes: gaseous, liquid, semisolid, and solid lubricants. (1) Gaseous lubricants, especially air, are used for lubrication where high speed and radial stability of the axis of rotation are desired; abnormal temperature conditions or the presence of nuclear beams have emerged. (2) Liquid lubricants consist of a wide range of fluids, from pressurized liquefied gases to various synthetic oils. Application of liquid lubricants comprises a wide range of requests for under pressure gases, various synthetic oils, etc. They are consumed for hydrodynamic lubrication operation with a thick layer or a thin layer of lubricant. Therefore, it is the most common type of lubricant used. The most important and widely used liquid lubricant is mineral oil obtained from crude oil refining. Liquid lubricants comprise the following: Natural, animal, and vegetable oils that have specific lubrication use. These oils are the product of fatty acids with alcohol, which were used alone for fluids lubrication in the past. But today, they are requested in combination with mineral oils. (3) Semisolid lubricants consist of various greases, solid fats, and waxes [1-8]. Uses of these lubricants are devoted to sealing the lubrication site to use liquid lubricant, light, and discontinuous working conditions or lack of access to the site in ball bearings and rollers that are lubricated by elastohydrodynamic lubrication operation. (4) Solid lubricants are used for lubrication in working conditions such as complete vacuum, the ambient with high

"Address correspondence to this author at the Department of Environmental science, UCS, Osmania University, Telangana State, India; Tel: 091-8978811723; E-mail: Malek.hassanpour@yahoo.com temperature, or in boundary lubrication conditions. This group was allocated for graphite, mica, talc, molybdenum sulfide, lead oxide, sulfur mud, and various plastics. Therefore, the outcome of huge demand in lubricant consumption can be impressive for the used lubricants released from a variety of applications in society. According to recent reports, the production rate of used liquid lubricants (motor oils) is about 300000-350000 tons/year in Iran [6-10]. The huge quantities of used liquid lubricants demand methods for managing the waste released.

Additives are chemical materials with particular compounds that add a certain quantity to the base oil to modify the basic properties of the oil and provide many promotions and modifications that either are not present in the base oil or they are minimum to the total oil proportion. The motor oil additives are mainly encompassed oxidation inhibitors, bearing corrosion agents, anti-abrasion materials, friction improvers, antifoaming agents, anti-paint additives, suspended ashfree builders, and metal cleaners [7-13].

Crude oil can be divided into several groups of compounds according to the percentage of its organic compounds (1) crude oil with paraffin base (2) crude oil with naphthenic base (3) crude oil with aromatic base. Approximate weight percentage analysis of a crude oil sample (by average weight) for carbon, hydrogen, sulfur, nitrogen, oxygen, and metals were reported as 83.9-86.8; 11.4-14; 0.06-8; 0.11-1.7; 0.5 ; and 0.03, respectively [13-16].

The main source of motor oil pollution is the materials produced from engine fuel combustion, so the type and quality of fuel, its combustion method, operating conditions, and mechanical situation of the 
engine are effective parameters in motor oil pollution. UMO often contains solid impurities such as dust, sand, metal particles, carbon lead residues, etc., which are harmful components to engine operation. At high temperatures and in the presence of oxygen, the metal particles in the motor oil act as a catalyst, create asphalt and sludge materials that promote the oil's viscosity to some extent. Paraffin oils keep the asphalt materials in a soluble state so that they do not precipitate as hard charcoal when heated. Petroleum oils or oils with cleansing properties prevent scale and flake formation [16-20].

Before examining the different methods of producing motor oil and grease from the UMO, we must first see the other benefits of re-refining the UMO in addition to using the final product and what is its application in other demands. Suppose that all the massive quantity of UMO is collected under the correct procedure and methods. The question that arises is; what is the correct and optimal way to use the UMO? Three options can be discussed in this regard. (1) Release to the environment (2) incineration of UMO as fuel (3) reprocessing or re-refining. Since the pollutants in the UMO are insoluble and pollute the ground, they cause environmental problems, and the soluble pollutants also pollute the underground resources. So, these wastes are very problematic. They are more dangerous than primary pollutants, so the use of UMO, in addition to economic justifications, also finds more environmental challenges. At a simple glance, the UMO re-refining seems like crude oil refining because it has all the required properties for fuel and base oil production. These properties can be mentioned, for example, (1) good viscosity, (2) good viscosity index (3) low pour point. Before transferring to the tank of base oil, the crude oil needs the removal of contaminants (water, light hydrocarbons, ash, and components of asphalt). Simultaneous adjustment of secondary characteristics is essential parts such as color and $\mathrm{pH}$. The difficulty experienced is related to finding the technology for purifying the UMO in the areas mentioned above. This technology must have acceptable conditions from the following points of view. (1) Ecology or environmental protection (control of released pollutants and their removal); (2) Performance (extraction rate and specifications) (3) Cost. The appropriate response for a given situation depends on the severity of the regulations on the prevention of environmental pollution in the area. According to estimations, the production of one ton of base oil through conventional processes based on crude oil of
Middle Eastern countries, which is suitable for oil production, requires 1.6-1.4 tons of gasoline, i.e., crude oil, and the required energy of oil production from crude oil. The same estimation based on UMO re-refining shows that the production of one ton of base oil equivalent to 1.1-1.2 tons of gasoline is required (assuming the value of gasoline-equivalent to UMO is between 0.8-0.9 tons per ton of UMO and extraction of $72.5 \%$ of UMO). This gives an advantage in re-refining UMO compared to the normal process between 0.2 to 0.4 tons per ton of base oil produced. In addition, it should be noted that the production of one ton of base oil through conventional processes will require refining 6.5-10 tons of crude oil (depending on the type of oil and the specific characteristics of treated motor oil). According to initial estimations of the Iranian experts, per 1000 tons of crude oil, 5 tons of motor oil is extracted. Re-refining UMO leads to the purchase and use of smaller quantities of crude oil mixed with UMO. The re-refining is not destructive and, in addition, will create job opportunities [18-21].

The dewatering unit of UMOR is an integral process of all recycling technologies. The yield of released water is estimated at approximately $4 \%$ of the input feed of UMO. The released water in the grease production process from the UMOR is about 0.1 to $0.3 \%$ by weight of the produced grease in acid/clay recycling technology. The dehydration stage of the UMO is an integral part of the employed processes and technologies to recycle the UMO. This unit is known in large refineries as water intake ponds. It is located before the distillation and heating units of UMOR. Due to the qualities and quantities of collected UMO and the requested fresh motor oil, there is not even one recovery method in the recycling process that is considered an optimal alternative under all conditions. In the dehydration process in the tanks, ponds of UMO, water (insoluble), and waste are removed via discharging and loading during the specified retention time. These materials drain some water to some extent. Filters are sometimes placed on these ponds or tanks to remove larger impurities and simplify the work. In any case, the lower phase (water and other sediments) is discharged from the tank, and the upper phase is sent to the distillation tower by a pump. In the past, when the collected oils were less complex in the production units, the oil was sent to the dewatering unit and was heated to a temperature above $100^{\circ} \mathrm{C}$. In this way, the remaining water was taken from the oil, but now for the above reasons and other reasons like the oil being not efficient during the process, after settling 


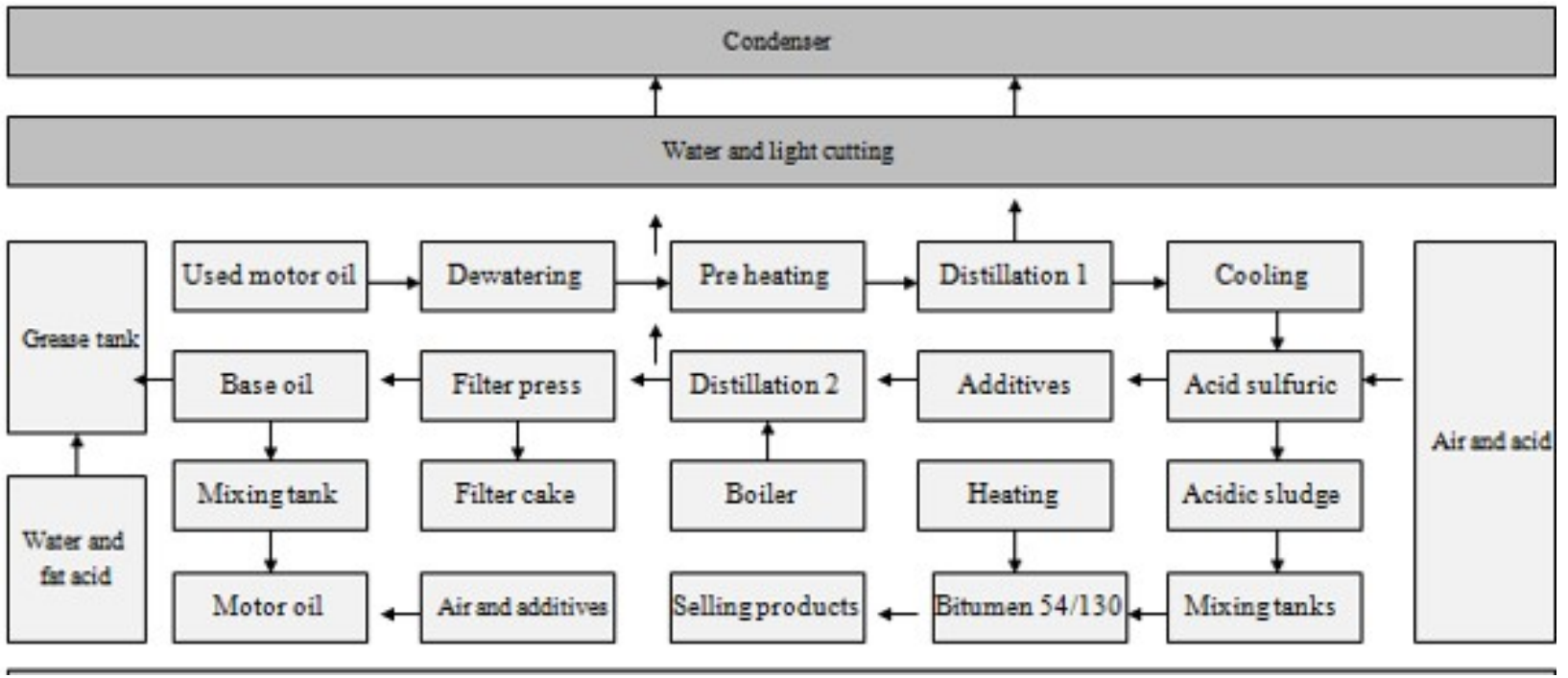

Figure 1: UMO reprocessing industry and AS recycling unit joined [24].

tanks, the oil is sent to a heat exchanger (by passing through a preheating) and then to the distillation tower in acid/clay recycling technology. The acid/clay technology is a dominant technique in recycling UMO in Iran and too many nations worldwide. It has been reported to the existence of at least 250 small industries in recycling UMO in Iran. Figure 1 displays the layout of acid/clay technology units in UMOR operation in Iran [19-23].

\section{INDUSTRIAL APPLICATIONS OF AS}

AS as an industrial waste of UMOR industries is utilized in various applications in both forms of additive material and supplementary material in the manufacturing operation [25-30]. The most important applications of AS in industrial requests are included in manufacturing organic fertilization, explosive materials, paint, ink, industrial detergent, sulfuric acid, light hydrocarbons, coke, activated carbon, furnaces fuel, boilers fuel, thermal insulation, plastic bags, automotive fan belt, PVC flooring, blown bitumen, emulsion bitumen, polymer bitumen, complementary of bitumen (optimum ratio of AS applied as an additive in bitumen $60 / 70$ obtained to be around $20 \%$ of its weight), motorcycle battery, and liquid bitumen, etc. [30-38]. According to the environmental impact assessment report of Iranian industrial projects, we have access to initial data of both manufacturing units of printing ink and thermal insulator. The initial data of mentioned industries has been discussed in the following sections. Figure 2 shows the modified AS of UMO reprocessing industries to polymer bitumen using bentonite and styrene butadiene styrene polymer.

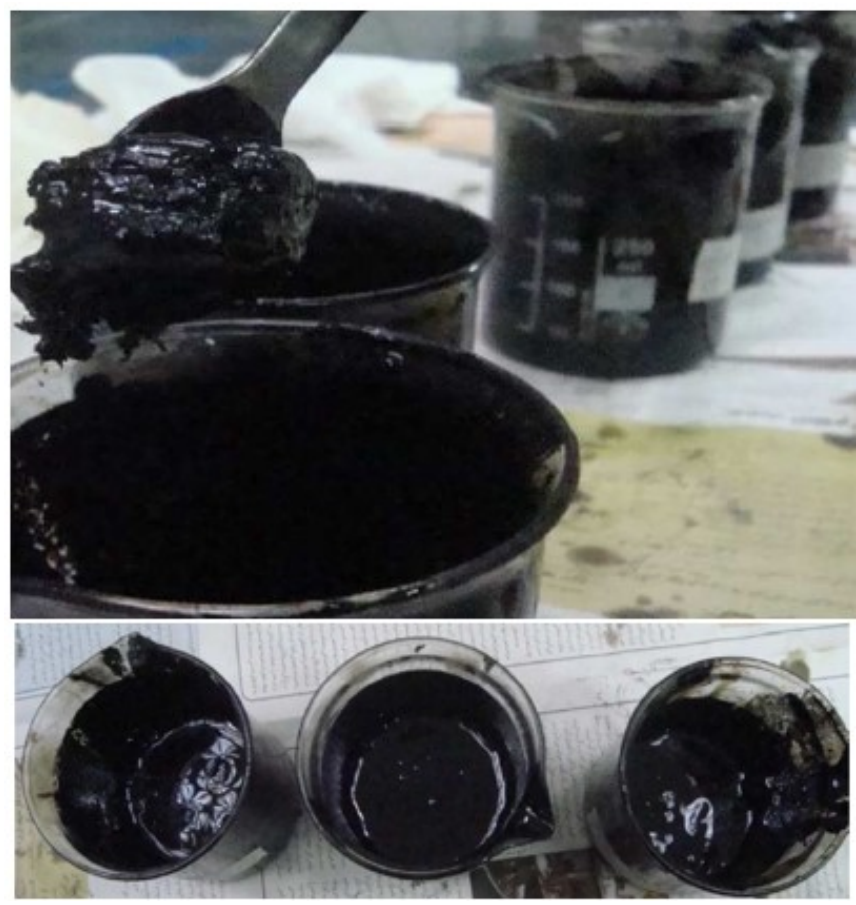

Figure 2: Shows the modified AS of UMO reprocessing industries to polymer bitumen [39].

In the latest studies, the structure and backbone of AS were considered by a few scientists via physicalchemical analysis tests. Despite the fact that we know AS of UMO is classified in the list of hazardous waste materials of environment protection agency, awareness of its composition helps the scientist investigate the relevant and proper managing practices [40-43]. Tables 1 and 2 portray the concentration of elements in AS of UMO reprocessing industries and their properties, respectively. 
Table 1: Concentration of Elements in AS of UMO Reprocessing Industries

\begin{tabular}{|c|c|c|c|c|c|c|c|c|c|c|c|}
\hline \multicolumn{11}{|c|}{ Element } & $\begin{array}{c}\text { References } \\
{[44]}\end{array}$ \\
\hline 0.22 & 0.04 & 0.14 & 0.32 & 17.3 & 0.05 & 0.01 & 0.13 & 0.27 & 3.71 & 10 & \\
\hline 220 & 15 & 20200 & 320 & 88 & 1 & 790 & $<0.1$ & $<0.1$ & 19100 & 130 & \\
\hline Sn & Sc & $\mathrm{Na}$ & $\mathrm{Ti}$ & $\mathrm{Hg}$ & As & $\mathrm{Bi}$ & Cd & Co & $\mathrm{Cr}$ & $\mathrm{Cu}$ & \\
\hline La & Mo & $\mathrm{Fe}$ & Mn & $\mathrm{Ni}$ & $\mathrm{Pb}$ & v & $\mathrm{Zn}$ & $\mathrm{Ag}$ & $\mathbf{G a}$ & MgO & \\
\hline$\leqslant 0.01$ & 70 & 1160 & 25 & 15 & 30 & $<0.1$ & 1100 & $<0.01$ & $<0.01$ & 530 & \\
\hline MnO & MO & SrO & $\mathrm{V}_{2} \mathrm{O}_{5}$ & $\mathrm{ZnO}$ & Ga & $\mathrm{P}_{2} \mathrm{O}_{5}$ & $\mathrm{Cr}_{2} \mathrm{O}_{3}$ & $\mathrm{CuO}$ & $\mathrm{Fe}_{2} \mathrm{O}_{3}$ & $\mathrm{PbO}$ & \\
\hline 32 & 105 & 154 & $<0.1$ & 1370 & $<0.01$ & 1810 & 48 & 110 & 1658 & 35 & \\
\hline $\mathrm{SO}_{2}$ & $\mathrm{SnO}_{2}$ & Cd & $\mathrm{CoO}$ & $\mathrm{Na}_{2} \mathrm{O}$ & $\mathrm{CaO}$ & $\mathrm{As}_{2} \mathrm{O}_{3}$ & $\mathrm{NiO}$ & $\mathrm{Al}_{2} \mathrm{O}_{3}$ & $\mathrm{~K}_{2} \mathrm{O}$ & $\mathrm{Sb}_{2} \mathrm{O}_{5}$ & \\
\hline $\mathrm{Zn}$ & $\mathrm{Cu}$ & $\mathrm{Fe}$ & Mo & B & Mn & Al & $\mathrm{Pb}$ & $\mathrm{Cr}$ & $\mathrm{Ba}$ & Sn & {$[46]^{*}$} \\
\hline 12248.7 & 4420.46 & 4033.58 & 2269.54 & 1369.36 & 398.06 & 273.02 & 132.7 & 119.09 & 110.33 & 58.65 & \\
\hline $\mathrm{Ni}$ & V & $\mathrm{Ag}$ & As & Cd & Co & $\mathrm{Hg}$ & Sb & Se & $\mathrm{Ti}$ & $\mathrm{Be}$ & \\
\hline 56.01 & 8.28 & 6.18 & 4.96 & 4.44 & 3.78 & 3.49 & 2.88 & 0.14 & 0.13 & 0.01 & \\
\hline $\mathrm{Li}$ & Sr & & & & & & & & & & \\
\hline 47.92 & 43.33 & & & & & & & & & & \\
\hline
\end{tabular}

The concentration of elements and oxides (ppm).

${ }^{*} \mathrm{mg} \mathrm{kg}^{-1}$

Table 2: Properties of AS [45-48]

\begin{tabular}{|c|c|c|c|}
\hline Property & Value & Test method & Unit \\
\hline Odor & Damaging & - & - \\
\hline $\mathrm{pH}$ & 1.35 & - & - \\
\hline Physical shape & Semisolid (at $25^{\circ} \mathrm{C}$ ) & & \\
\hline Penetration grade $\left(25^{\circ} \mathrm{C}\right)$ & 28 & ASTM D5 & $0.1 \mathrm{~mm}$ \\
\hline Ductility $\left(25^{\circ} \mathrm{C}\right)$ & 40 & ASTM D113 & $\mathrm{Cm}$ \\
\hline Melting point & 109 & ASTM D92 & ${ }^{\circ} \mathrm{C}$ \\
\hline Organic carbon & 542.44 & & $\mathrm{~g} / \mathrm{kg}$ \\
\hline TKN & 9.96 & & $\mathrm{~g} / \mathrm{kg}$ \\
\hline TP & 2.22 & & $\mathrm{~g} / \mathrm{kg}$ \\
\hline Water & 3 & & $\%$ \\
\hline Organic oil & 53 & & $\%$ \\
\hline Resins & 5 & & $\%$ \\
\hline Ash/other impurities & 0.15 & & $\%$ \\
\hline Asphaltene & 38.8 & & $\%$ \\
\hline Flash point & 210 & & ${ }^{\circ} \mathrm{C}$ \\
\hline Specific gravity & 1.1 & & $25^{\circ} \mathrm{C}$ \\
\hline
\end{tabular}


The industrial applications of AS can create job opportunities, business excellence, and sustainability of manufacturing units. The sustainable development of industrial units is the final and prominent purpose of environmental assessment and environmental management for various organizations. The privileges of sustainability in managing AS of reprocessing industries undermine part of the challenges raised about global warming.

\subsection{Printing Ink}

Since most of the newspapers are written in black ink, it is possible to choose the appropriate formulation according to the time of consumption and the storage period of the newspapers (which is a shorter time compared to the book). Production methods are almost similar for different types of inks; only the percentage of composition and types of employed raw materials are different. There are generally two methods for producing printing ink: in the first method, the pigment is mixed with varnish and then distributed via a supportive machine. The second method uses the cake pressing process. This means that the obtained dough from the production line is not dried and milled in the factory of making dough pigments. But in the same way, it is placed in a suitable chamber, and a vacuum pump removes the excess water. Then, the pigment is ready for consumption, and when needed, the varnish is added and mixed to be ready to use. This method is superior to the method of using dry pigment. The distribution of which requires a lot of mechanical energy because the color strength and gloss of the pigment compound prepared by the press cake method are better than the same type as a dry pigment. In European countries, the reason for not using this superior method gets back the limitation of the ink producer and the impossibility of using creativity for producing special inks. Because in the cake pressing method, a multifunctional varnish (a mixture of varnishes, oils, and additives) is selected and a pigment is distributed and dissipated in the required quantity, and the ink is ready to be used. So, the difficulty in ink producer is removed (preparation of a compound with particular properties, change in the properties of the ink, and solving the problems during printing). Using dry pigments for works of art is preferable because today, the problem of sealant and pigment distribution has been solved by preparing easy disperse sealants. But for making newspaper and offset printing, inks can be used.

To produce newspaper inks, first gilsonite, linseed oil, mineral oil, or other drying oils (according to the weighing formulation, if any) are poured into the relevant tank that is heated through a steam jacket. This process continues for 5-4 hours at a temperature of $170^{\circ} \mathrm{C}$. The resulting mixture, called a binder, is discharged from the tank by a pump and, after passing through a filter, enters a tank equipped with a wheel. The process involves introducing a carbon black pigment or soot into the specified amount and filler, which dissolves the soot particles into the liquid using a rapid stirrer to form a completely homogeneous suspension. The required time to mix is half an hour. The next is the aeration process, which takes place at the same time as the continuous packing process. It takes 3 to 2 hours, depending on the selected capacity. The process of aeration and milling of the materials causes better mixing of soot and composite filler, after which they are ready for packaging. As explained in the previous section, a 5-rollers or 3-rollers mill can be employed vertically or horizontally. The selected additive (lead naphthenate) is introduced at this stage, which acts as a desiccant. However, after this stage, the prepared ink is simultaneously directed to the filling machine, emptied, and then packaged in the desired containers to be presented to the market. Offset ink production is similar to the production of newspaper ink except for raw materials introduced into the production line and several other minor disorders. Thus, the raw materials required to produce offset composite binders are phenolic resin, desiccant oil, and high boiling point mineral oil obtained from oil cutting. According to the weighing formulation, the tank is equipped with an internal mixer, with the same temperature conditions and with the same mixing time. Since the oil cut would have a lower boiling point than the oil cut used in the newspaper, the mixing operation can be completed only by stirring, and there is no need to heat. In any case, after stirring the mixture for 4 hours and then draining it with a pump and passing it through a strainer, the next step is mixing with pigments and filler (hydrated calcium carbonate), which is done in a tank equipped with a wheel. Then naphthenate cobalt is added and mixed during aeration. The production process is the same as offset ink. Figure $\mathbf{3}$ and Table $\mathbf{3}$ display the layout of the units of the printing ink production industries and their annual requirements.

\subsection{Thermal Insulator}

The raw materials for making the product are (1) Tissue; it is a thin layer of fiberglass that has a width of 1 meter and is produced in the Iran Glass Wool Factory. (2) Polyester weighing 100 to $110 \mathrm{gm}^{-2}$, which 


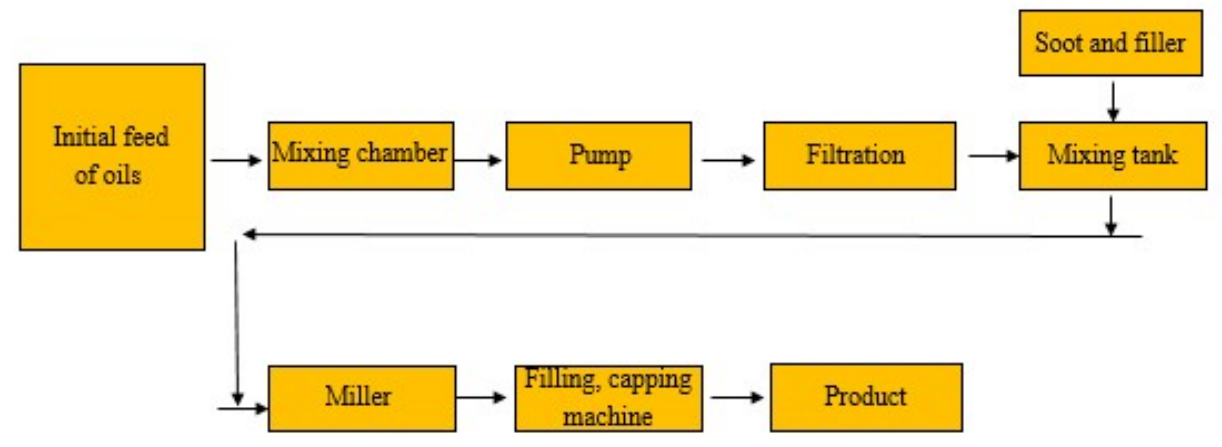

Figure 3: The layout of the units of printing ink production industries.

Table 3: The Annual Requirements of Industries of Printing Ink

\begin{tabular}{|c|c|}
\hline The materials and equipment & Total annual rates \\
\hline The reactor, capacity of $2000 \mathrm{~L}$, stainless steel, $20 \mathrm{hp}$ & 1 No \\
\hline Separator, $35 \mathrm{~L}$ & 1 No \\
\hline Box filter, steel, $A=1 \mathrm{~m}^{2}$ & 2 No \\
\hline Wheelbarrow, $1000 \mathrm{~L}$ & 1 No \\
\hline Mixer, $50 \mathrm{hp}$ & $1 \mathrm{No}$ \\
\hline Hydraulic three rollers miller & 1 No \\
\hline Filling machine, $1 \mathrm{~kg} / \mathrm{s}$ & $1 \mathrm{No}$ \\
\hline Labeling machine, 1 cans/s & $1 \mathrm{No}$ \\
\hline Naphthenate Cobalt & $5050 \mathrm{~kg}$ \\
\hline Phenolic resin & $15150 \mathrm{~kg}$ \\
\hline Cotton oil & $137360 \mathrm{~kg}$ \\
\hline Mineral oil & $130795 \mathrm{~kg}$ \\
\hline Carbon black & $68175 \mathrm{~kg}$ \\
\hline Titanium oxide & $3370 \mathrm{~kg}$ \\
\hline Azo pigments & $3370 \mathrm{~kg}$ \\
\hline Phthalocyanine & $3370 \mathrm{~kg}$ \\
\hline Artificial $\mathrm{SiO}_{2}$ & $505 \mathrm{~kg}$ \\
\hline Cardboard of packaging & $21042 \mathrm{~kg}$ \\
\hline Power & 229 kW/day \\
\hline Required fuel (Stoves) & 3 Giga Joule/day \\
\hline \multicolumn{2}{|c|}{ Required land and landscaping } \\
\hline Required land & $3300 \mathrm{~m}^{2}$ \\
\hline Construction of infrastructure (Buildings) & $930 \mathrm{~m}^{2}$ \\
\hline
\end{tabular}


gives the product the necessary strength. (3) A label of propylene according to the climate of the regions. (4) $\mathrm{CaCO}_{3}$ is a mineral material used as a filler and a nonadhesive layer. (5) Bitumen $80 / 25$ is the main material used to produce insulators, and for its production, additional aeration facilities are requested. (6) Polyethylene film, which is used as a coating. The method for producing the insulation layer is introducing the molten bitumen into the mixer at high temperature and then adding the propylene and asbestos labels to it and stirring. While stirring in the mixer, it is heated with hot oil until the temperature reaches $220^{\circ} \mathrm{C}$. Stirring continues for about 2 hours so that the ingredients are thoroughly mixed and emerged homogeneously. Then the resulting ingredients enter another mixer, and with increasing $\mathrm{CaCO}_{3}$ filler, the resulting mixture is concentrated and ready to work. The material enters the molten material pool from the second mixer in the layering machine. Inside this machine, the tissue and polyester layer is flattened via two rollers and is transferred to the place of the molten pool of materials by other rollers. They then enter the pool and are mixed thoroughly with the molten material. After that, the mentioned layer is removed from the melt pool and cooled by a water pool or air pressure. After coming out of the water pool, $\mathrm{CaCO}_{3}$ powder is added to separate and prevent the layers from attaching. They are then calibrated by special rollers. A layer of polyethylene film is placed on it and adheres to it by roller pressure. Quality control is done in all stages. In Iran, the production method of asphalt sheets and shields of moisture insulator and non-moist prefabricated asphalt coating has been available for a long time, and all devices and manufacturing technology are produced in the country. The method of producing insulators is that initially, bitumen $80 / 25$, which is melted at $80^{\circ} \mathrm{C}$, is introduced into the high-speed mixer. Then the addition of the solution of propylene and the asbestos that has already been mixed with it is completed. Since the mixer is a double-walled reactor, it is heated by hot oil. It handles the temperature around the boiler to be escalated about 220 to $230^{\circ} \mathrm{C}$. Stirring continues for about 2 hours until the ingredients are well mixed and the thermostatic operation is performed. The required percentage of $\mathrm{CaCO}_{3}$ is then added, and the additives are introduced into the reactor. The produced primer is sent to the storage tank of intermediate materials, after which the tissue of glass wool layer along with a roll of polyester is connected to the machine. After that, it enters the tank and is impregnated with the primer. This layer is cooled slowly, and with the cooling process, the vapors are evaporated, and odorous gases are absorbed. Then $\mathrm{CaCO}_{3}$ powder is sprayed, and a layer of polyethylene film is accommodated on it to be rolled. It has a dimension of around $1 * 10 \mathrm{~m}^{2}$. This method is one of the best, easiest, and least expensive methods of producing insulators. According to the needs of the device, automation systems are connected to it, and drying the insulator is done by introducing air. Figure $\mathbf{4}$ and Table $\mathbf{4}$ denote the layout of the units of insulator production industries and their annual requirements.

\section{CONCLUSION}

All UMO treatment processes produce a significant quantity of Contaminated Water (CW). The CW discussed in this review includes contaminated water for washing industrial units and water released from the heating unit, preliminary distillation, and distillation operation. The dewatering unit of UMOR is an integral process of all purification technologies. The yield of released water is estimated at approximately $4 \%$ of the input feed of UMO. The handling methods of AS have been facilitated using new data and reports published. The tabulated data attracts the stakeholders to conduct

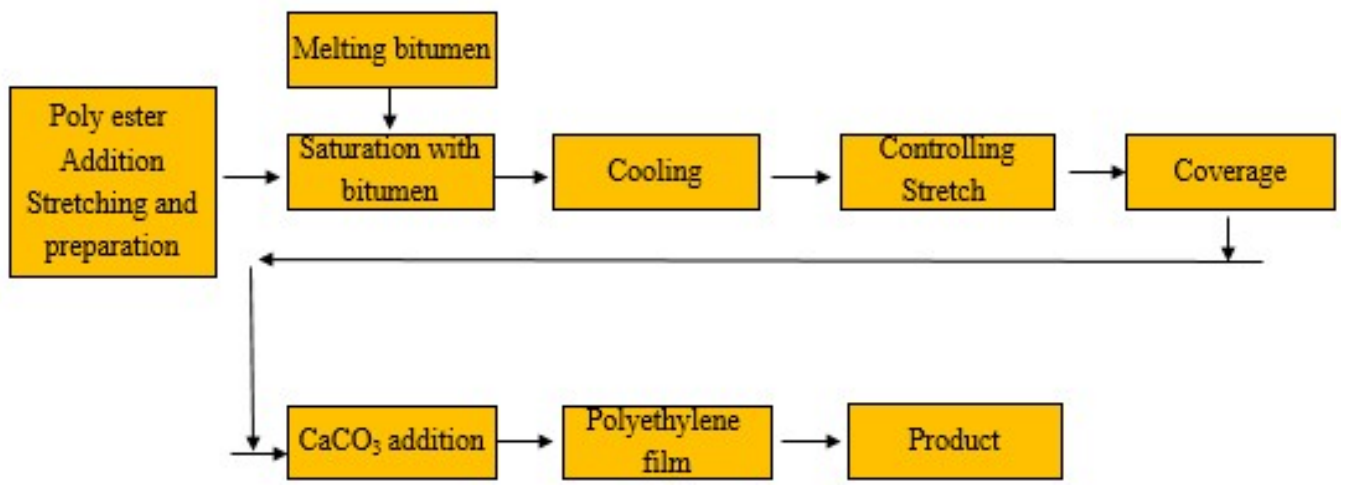

Figure 4: The thermal insulator manufacturing process. 
Table 4: The Annual Requirements of Thermal Insulator Manufacturing Industries

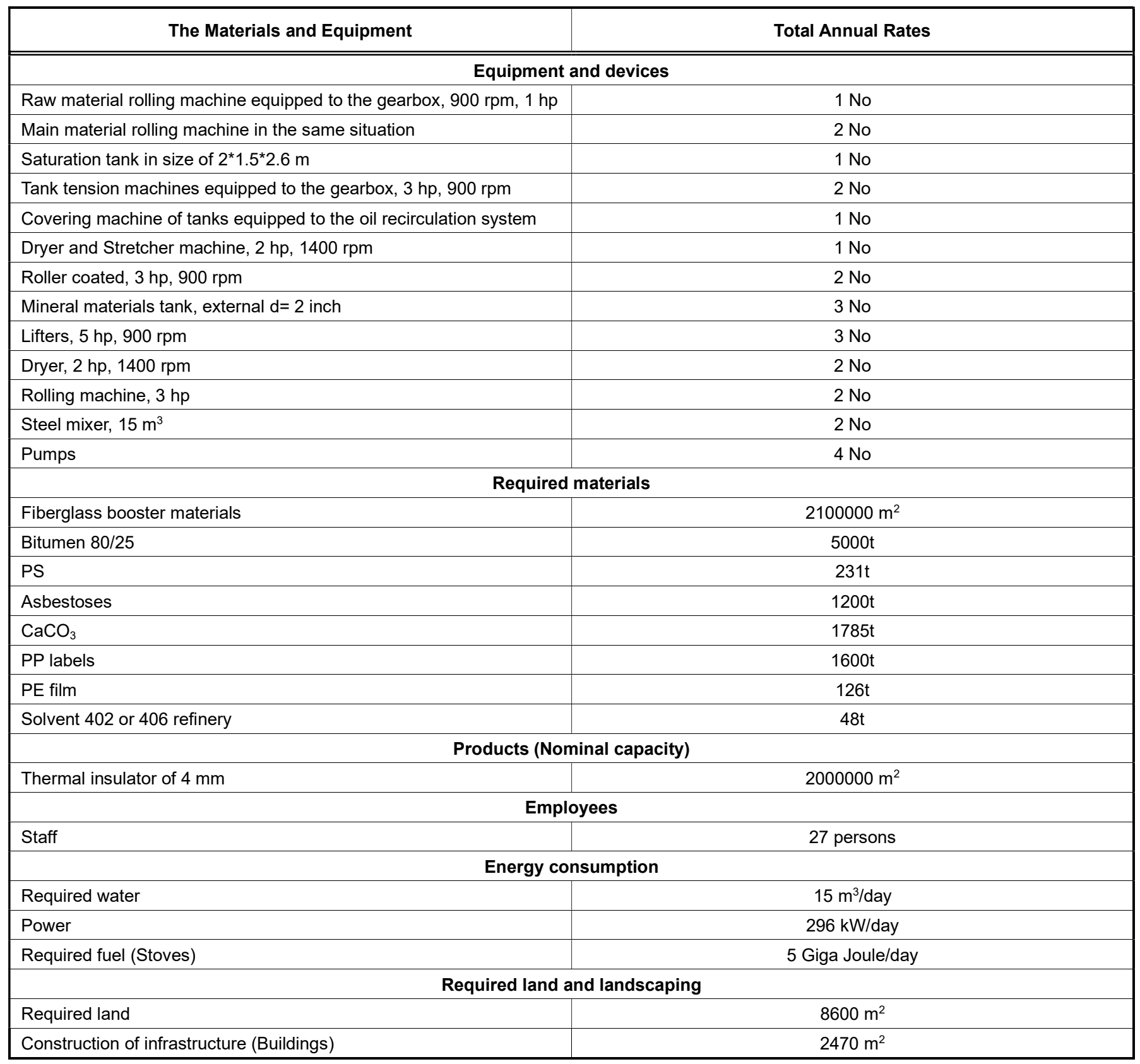

an economic assessment from their running industrial units. The financial modeling can also be defined as another achievement of the tabulated data. The tabulated data was picked up from the industrial project initial screening step in the environmental impact assessment plan. They can be used to figure out the performance and efficiency of industrial units via data envelopment analysis. Future research orientation is recommended to be moved towards plasmatron gasification of AS to generate value-added gaseous products such as $\mathrm{CH}_{4}, \mathrm{CO}_{2}, \mathrm{CO}, \mathrm{N}_{2}$, and $\mathrm{O}_{2}$.

\section{ACKNOWLEDGMENT}

This research was conducted as part of the corresponding author's Ph.D. research work (Entitled; Evaluation of 405 Iranian Industries). The tabulated data were picked up from the screening step of project identification in environmental impact assessment. The author thanked colleagues and evaluators of both the Iranian environment protection agency and Iranian industries organization for the data assessed. 


\section{COMPETING INTERESTS}

The author declares that there is no competing interest.

\section{CONFLICT OF INTEREST}

There is no conflict of interest.

\section{FUNDING}

None.

\section{ETHICAL CONSIDERATIONS}

Ethical issues have been completely observed by the author.

\section{REFERENCES}

[1] Eving BT, Thompson MA. Dynamic cyclical co-movements of oil prices with industrial production, consumer prices, unemployment, and stock prices. J Energy Policy 2007; 35(11): 5535-5540.

https://doi.org/10.1016/j.enpol.2007.05.018.

[2] Hsu YL, Liu CC. Evaluation and selection of waste lubricating oil technology. Environ. Monit. Assess, 2011; 176:1-16.

https://doi.org/10.1007/s10661-010-1576-3.

[3] Katiyar V, Husain S. Reclamation of used lubricating oils. Curr. World Environ 2010; 5 (1): 79-84.

[4] Abdel-Jabbar NM, Al Zubaidy EAH. Waste lubricating oil treatment by adsorption process using different adsorbents. World Acad. International Journal of Chemical and Biological Engineering 2010; 3(2): 64-68.

[5] Hani FB, Al-Wedyan $\mathrm{H}$. Regeneration of base-oil from wasteoil under different conditions and variables. Afr. J. Biotechnol 2011; 10 (7): 1150-1153.

DOI: $10.5897 / A J B 10.1791$.

[6] Hatami AM, Sabour MR, Amiri A. Recycling process of spent bleaching clay: Optimization by response surface methodology. Global J. Environ. Sci. Manage 2018; 4(1): 918.

DOI: 10.22034/gjesm.2018.04.01.002.

[7] Rincon J, Canizares P, Garcia M, Gracia I. Regeneration of used lubricant oil by propane extraction. Ind. Eng. Chem. Res 2003; 42: 4867-4873.

https://doi.org/10.1021/ie030013w.

[8] Kalnes T. Treatment and recycling of waste lubricants. A petroleum refinery integration study. In: AICHE National Meeting, San Diego, CA, 1990; 19-22.

[9] Hamad A, Al-Zubaidya E, Fayed ME. Used lubricating oil recycling using hydrocarbon solvents. Environ. Manage 2005; 74: 153-159.

https://doi.org/10.1016/j.jenvman.2004.09.002.

[10] Ogbeide SO. An investigation to the recycling of spent engine oil. Eng. Sci. Technol. Rev 2010; 3 (1): 23-35.

[11] Bongfa B, Syahrullail S, Hamid MKA, Samin PM, Atuci B, Ajibili HE. Maximizing the Life of Lubricating Oils for Resources and Environmental Sustainability through Quality Monitoring in Service. Indian Journal of Science and Technology 2016; 9(48): 1-10.

DOI: $10.17485 /$ ijst/2016/v9iS1/109630.
[12]

Syrmanova KK, Kovaleva AY, Kaldybekova ZB, Botabayev NY, Botashev YT, Beloborodov BY. Chemistry and Recycling Technology of Used Motor Oil. Orient. J. Chem 2017; 33(6): 3195-3199.

http://dx.doi.org/10.13005/ojc/330665.

[13] Tsai WT. An analysis of used lubricant recycling, energy utilization and its environmental benefit in Taiwan. Energy, 36 (2011) 4333-4339.

https://doi.org/10.1016/j.energy.2011.04.008.

[14] Chen X, Xu R, Xu Y, Hu H, Pan S, Pan H. Natural adsorbent based on sawdust for removing impurities in waste lubricants. Journal of Hazardous Materials 350 (2018) 38-45. https://doi.org/10.1016/j.jhazmat.2018.01.057.

[15] Pinheiro CT, Pais RF, Quina MJ, Gando-Ferreira LM Regeneration of waste lubricant oil with distinct properties by extraction-flocculation using green solvents. Journal of Cleaner Production 200 (2018) 578-587.

https://doi.org/10.1016/j.jclepro.2018.07.282.

[16] Aksenov VI, Tsarev NS, Yasnitskaya KV. Treatment of the Combined Sludges of Machine Factories. Procedia Engineering 150 (2016) $2405-2408$. https://doi.org/10.1016/j.proeng.2016.07.302.

[17] Farzanegan MR, G Markwardt. The effects of oil price shocks on the Iranian economy. Energy economics. 2009; 31(1): 134-151. https://doi.org/10.1016/j.eneco.2008.09.003.

[18] Ahmad I, Khan R, Ishaq M, Khan H, Ismail M, Gul K. Catalytic Pyrolysis of Used Engine Oil over Coal Ash into Fuel-like Products. Energy Fuels 2016; 30: 204-218. https://doi.org/10.1021/acs.energyfuels.5b02316.

[19] Desalegn B, Megharaj M, Chen Z, Naidu R. Green mango peel-nanozerovalent iron activated persulfate oxidation of petroleum hydrocarbons in oil sludge contaminated soil. Environmental Technology \& Innovation 11 (2018) 142-152. https://doi.org/10.1016/j.eti.2018.05.007.

[20] Boadu KO, Joel OF, Essumang DK, Evbuomwan BO. A Review of Methods for Removal of Contaminants in Used Lubricating Oil. Chemical Science International Journal 2019; 26(4): 1-11.

DOI: $10.9734 / C S J I / 2019 /$ v26i430101.

[21] Gryazin V, Bagautdinov T, Kozlov K, Belogusev V. Tool for quality control of lubricants. Engineering for rural development 2018; 943-947.

DOI: 10.22616/ERDev2018.17.N411.

[22] Oladimeji TE, Sonibare JA, Omoleye JA, Emetere ME, Elehinafe FB. A review on treatment methods of used lubricating oil. International Journal of Civil Engineering and Technology (IJCIET) 2018; 9(12): 506-514. http://eprints.covenantuniversity.edu.ng/id/eprint/13563.

[23] Kavak A, Bilgen G, Mutman U. In-situ modification of a road material using a special polymer. Sci. Res. Essays 2010; 5(17): 2547-2555. https://doi.org/10.5897/SRE.9000583.

[24] Hamidi Y, Sarafi A, Tahmoresi M. Effect of addition bentonite to the rubber tar, 12th National Iranian chemical engineering Congress. 2010.

[25] Hassan Z, Hassan D, Rezvan B, Ali A. Influence of Bentonite Additive on Bitumen and Asphalt Mixture Properties. World Academy of Science, Engineering and Technology 6 (2012) 08-24.

[26] Saleh NJ, Muslim MA. A Study of the Effect of Iraqi Bentonite on Some Properties of Polymeric Blend. Eng \& tech 31 (2013) 50-61.

[27] Chen JS, Liao MC, Lin CH. Determination of Polymer Content in Modified Bitumen. Materials and Structures 2003, 36(9), 594-598.

https://doi.org/10.1007/BF02483278. 
[28] Sengoz B, Isikyakar G. Evaluation of the Properties and Microstructure of SBS and EVA Polymer Modified Bitumen. Construction and Building Materials 2009; 22(9): 1897-1905. https://doi.org/10.1016/j.conbuildmat.2007.07.013.

[29] Hamid B, Hassan Z, Shams N. The Use of Polymer Modification of Bitumen for Durant Hot Asphalt Mixtures. Applied Sciences Research 4 (2008) 96-102.

[30] Kok VB, Akpolat M. Effects of Using Sasobit and SBS on the Engineering Properties of Bitumen and Stone Mastic Asphalt. J. Mater. Civ. Eng 2015; 27(10): 1-7. https://doi.org/10.1061/(ASCE)MT.1943-5533.0001255.

[31] Abtahi S M, Dibaji SHA. Climatic zoning of Isfahan province to use of suitable bitumen based on PG. The $4^{\text {th }}$ National Congress on Civil Engineering, Tehran University, 2008.

[32] Asi IM. Performance evaluation of SUPERPAVE and Marshall Asphalt mix designs to suite Jordan climatic and traffic conditions. Construction and Building Materials 2007; 21(8): 1732-1740.

https://doi.org/10.1016/j.conbuildmat.2006.05.036.

[33] Shen J, Amirkhanian S, Tang B. Effects of rejuvenator on performance-based properties of rejuvenated asphalt binder and mixtures. Construction and Building Materials 2007; 21(5): 958-964.

https://doi.org/10.1016/j.conbuildmat.2006.03.006.

[34] Stelea L. Present Trends in Improving Quality of Pavement Bitumen. Construction Materials 2007; 4(4): 57-68.

[35] Cutler CJ. Net energy from the extraction of oil and gas in the United States. Energy 2005; 30(5): 769-782.

https://doi.org/10.1016/j.energy.2004.05.023.

[36] Bayo-Moriones A, Merino-D-az-de-Cerio J, Escamilla-de-Leo SA, Selvam RM. The impact of ISO 9000 and EFQM on the use of flexible work practices. Int. J. Production Economics 2011; 130(1): 33-42.

https://doi.org/10.1016/j.jpe.2010.10.012.

[37] Hassanpour M. Investigate the feasibility of recycling acidic sludge from used motor oil reprocessing industries to bitumen. Master thesis. Tehran University of Medical Science. 2013; 1-100.

[38] Krajnc D Glavic P. How to compare companies on relevant dimensions of sustainability. Ecological Economics. 2005; 55(4): 551- 563

https://doi.org/10.1016/j.ecolecon.2004.12.011.

[39] Musee N, Lorenzen L, Aldrich C. New methodology for hazardous waste classification using fuzzy set theory: Part I.
Knowledge acquisition. Hazard. Mater 2008; 154 (15): 1040 1051.

https://doi.org/10.1016/j.jhazmat.2007.11.011

[40] Hu G, Li J, Zeng G. Recent development in the treatment of oily sludge from petroleum industry: a review. Hazard. Mater 2013; 261(15): 470-490.

https://doi.org/10.1016/j.jhazmat.2013.07.069.

[41] Bridjanian H, Sattarin M. Modern recovery methods in used oil re-refining. Pet. Coal 2006; 48 (1): 40-43.

[42] Shishehboran M, Ziari $H$, Korayem AH, Hajiloo $M$. Environmental and mechanical impacts of waste incinerated acidic sludge ash as filler in hot mix asphalt. Case Studies in Construction Materials 2012; 14: e00504.

[43] Asgari A, Nabizadeh R, Mahvi AH, Nasseri S, Dehghani MH, Nazmara S, Yaghmaeian K. Biodegradation of total petroleum hydrocarbons from acidic sludge produced by rerefinery industries of waste oil using in-vessel composting. Journal of Environmental Health Science \& Engineering (2017) 15(3) 1-9. https://doi.org/10.1186/s40201-017-0267-1.

[44] Hadadi V, Moradi A. A novel method for refining of acidic sludge and mixing with vacuum bottom to improve bitumen properties, Petroleum Science and Technology 2019; 1-12. https://doi.org/10.1080/10916466.2019.1573258

[45] Van Zyl T. Valorisation of Used Automotive Lubrication Oil. Dissertation submitted for the fulfilment of the requirements for the degree Master of Engineering in the Department of Chemical Engineering at Durban University of Technology 2019; 1-100.

http://hdl.handle.net/10321/3308.

[46] Small Industries Organization and industrial States of Iran. https://isipo.ir/.

[47] Iranian industries organization website. Evluation of industrial projects.

https://teh.mimt.gov.ir/.

[48] Charpentier J.-C. In the Framework of Global Trade, Sustainability and Industry Demand for Innovative Process and Technologies, what kind of Modern "Green" Chemical Engineering is required for the Design of "the Factory of the Future"? International Journal of Petroleum Technology 2019; 6(1): 7-29.

https://doi.org/10.15377/2409-787x.2019.06.2.

DOI: https://doi.org/10.15377/2410-3624.2020.07.6

(c) 2020 Malek Hassanpour. Published by Avanti Publishers.

This is an open access article licensed under the terms of the Creative Commons Attribution Non-Commercial License (http://creativecommons.org/licenses/by-nc/3.0/) which permits unrestricted, non-commercial use, distribution and reproduction in any medium, provided the work is properly cited. 